\title{
Determinants of ownership pattern
}

\author{
Daman Jeet $^{1{ }^{*} \text {, B.S. Bhatia }}{ }^{2}$, R.K. Sharma ${ }^{3}$ \\ ${ }^{\mathbf{1}}$ Research Scholar, ${ }^{\mathbf{2} 3}$ Professor, Sri Guru Granth Sahib World University, Fatehghar Sahib, Punjab, India
}

*Corresponding Author:

Email: damanjeetnitj@gmail.com

\begin{abstract}
Percentage of shares held is considered to be one of the primary measures of ownership structure as this ratio determines how a firm is owned and how the authority is distributed among owners. Studies have been conducted on interrelationships among corporate ownership and board structure characteristics and on the determinants and mechanism by which the ownership structure is formed. Broadly these studies only reflect on one or two governance characteristics with an exception by Agrawal and Knoeber, 1996. The inconclusive studies of ownership structure make it necessary to study the identity the determinants of ownership. Taking a proportionate sample of companies from the four major industries, this study tries to find the factors affecting ownership pattern. Captivating ownership as Indian and foreign promoters, financial performance measured using tobin's q and duality (chairman and managing director being single person) positively and significantly affect ownership. However, financial leverage negatively impacts ownership.
\end{abstract}

Keywords: ROA-Return on Assets, Tobin's Q, Corporate Governance.

\section{Introduction}

Ownership structure refers to the pattern of shareholdings of individuals or organizations in a company. Distribution of share ownership in terms of percentage held is considered to be one of the primary measures of ownership structure. It is measured as ratio of shares held by owner(s) to total number of company shares. This ratio determines how a firm is owned and how the authority is distributed among owners. Hence, it will provide basis to determine the concept of control and power in the company. Short (1994) squabbles that most of the previous studies empirically differentiate between owner controlled and management controlled firms are based upon percentage ownership criterion.

\section{Literature exploring the determinants of ownership pattern}

Berle and Means in 1932 brought up the issue that researchers have attempted to figure out ever since then, i.e. the determinants and mechanism by which the ownership structure is formed. Greater percentage of stocks owned by top managers gives them the right to take decisions that aid in maximizing shareholders' wealth (Jensen \& Meckling, 1976) as these choices will in turn maximize their own wealth. This way the ownership by managers aids in controlling agency problems. In addition, Fama, 1980 argues that the board of directors is the innermost internal control mechanism for monitoring managers. Three characteristics that influence the monitoring capability of a board are board size, board composition and board leadership structure (Jensen, 1993).

The role of corporate ownership and the board of directors as governance mechanisms have been subject to considerable empirical analysis. There have also been studies conducted on interrelationships among corporate ownership and board structure characteristics especially the one by Y.T. Mak \& Y. Li, (2001), determinants of corporate ownership and board structure. Another view is that ownership structure and board structure are endogenously determined. The costs and benefits of different ownership and board structures vary across firms. According to this view point, the corporate governance mechanisms of a particular firm imitate the tradeoffs between costs and benefits for that particular firm. Hence, apposite corporate governance mechanisms differ methodically across firms. Studies that have adopted this view include Demsetz and Lehn's (1985), study of the structure of corporate ownership, and Hermalin and Weisbach's (1988), study of board composition.

However, broadly, these studies only reflect on one or two governance characteristics, such as the proportion of outside directors or corporate ownership. An exception is the recent study by Agrawal and Knoeber, 1996 which considers multiple monitoring mechanisms.

Also, Ei Yet Chu \& Kooi Guan Cheah (2004) in their study, the determinants of ownership structure considered the governance issues under four heads;

1. Information asymmetry in terms of firm size, firm age etc.

2. Agency conflicts in terms of leverage, dividend.

3. Risk

4. Performance using ROA, tobin's q etc.

But the research by Y.T. Mak \& Y. Li, (2001) recognized the following antecedents of ownership pattern that included board composition as well: 


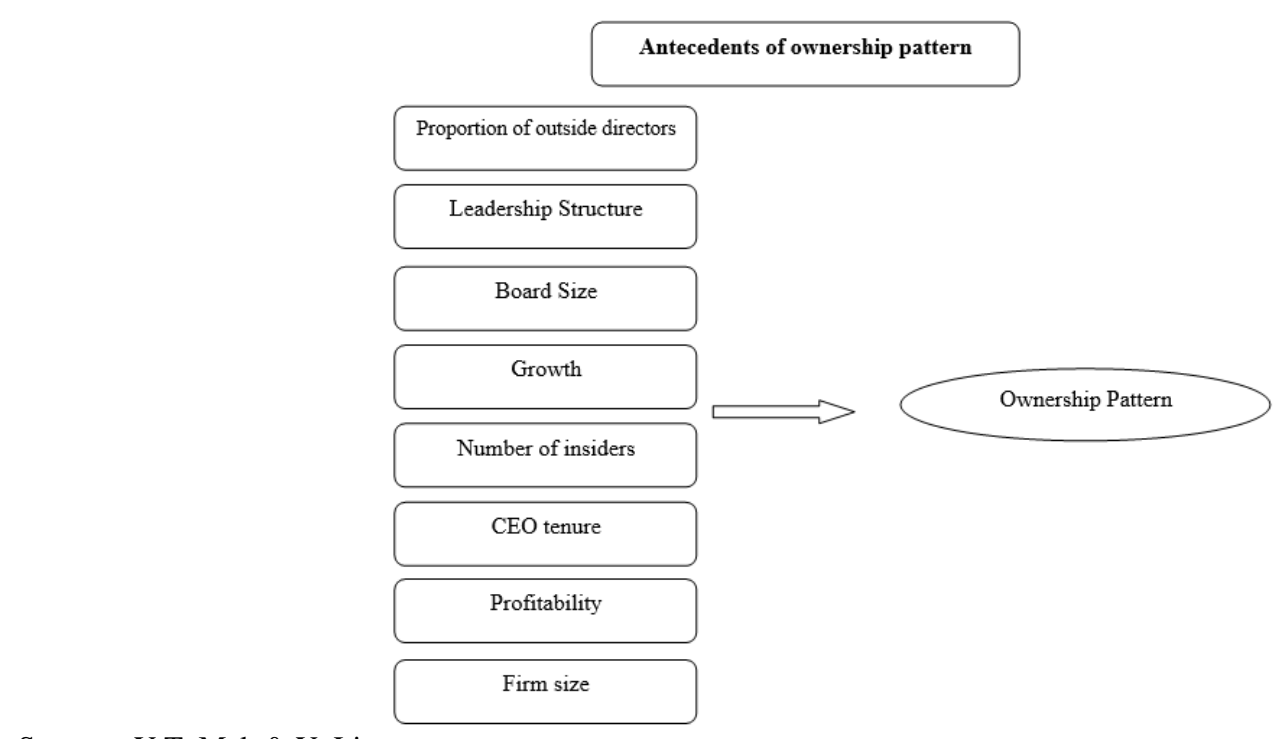

Sources: Y.T. Mak \& Y. Li

Fig. 1

The inconclusive studies of ownership structure make it necessary to study the identity of owners and shareholder concentration in a firm. This study is very significant due to two main reasons; first, ownership structures have an effect on the development and performance of capital and debt market and second ownership structure plays an important role in the governance of firms. It functions as monitoring and governance mechanism thereby enhancing firm's performance. The suggestion of this observation comes from Fama and Jensen (1983) and Short et al (2002). My study is based more on the works of Y.T. Mak \& Y. Li.

Traditionally, corporate ownership has been operationalized along two dimensions - managerial ownership e.g., Jensen and Meckling, 1976 and institutional ownership e.g., Shivdasani, 1993. In this study I have analyzed the factors taking promoters as proxy for ownership. Moreover, firms representative of all major industries i.e. construction, manufacturing, services and others have been taken for the paucity of this work.

\section{Sample and methodology}

In order to establish the determinants of ownership pattern, out of top 500 Indian companies constituting BSE500 index covering four major industries of the economy have been analyzed. Accord Fintech private limited provides access to financial and non financial information of Indian companies through the database, ACE equity. This database has been used as a source to extract financial information for study. Annual reports and ACE equity database both have been used in combination to extract data on various determinants of ownership pattern.

The study relates to the period from 1 April, 2011 to 31 March, 2016. Out of a total of 8,17,000 registered and active companies in India on 31 Oct 2017, 154 companies representing four major industry categories are taken as sample for the study. Proportionately 37 manufacturing, 59 services, 26 others and 32 were taken for construction. For exploring the determinants of ownership pattern variables for the current study have been categorized into three sub-headings:

Dependent variable: The aim of the study is to identify dimensions of ownership pattern in Indian context; hence ownership pattern is taken as dependent variable. In India, the shareholders are broadly divided into two categories-promoter shareholders and nonpromoter shareholders (Santanu K Ganguli and Shail Agrawal, 2008). This study takes promoters as proxy for ownership and for better and detailed study considers both; Indian promoter and foreign promoter shareholding separately. The variables representing ownership pattern are percentage of shares held by Indian promoters and percentage of shares held by foreign promoters.

Determinants of Ownership Pattern: The role of corporate ownership and the board of directors as governance mechanisms have been subject to substantial empirical analysis.

Berle and Means (1932) brought up the issue to figure out the factors and mechanism by which the ownership structure is formed and researchers ever since have attempted to work out the same. Findings in many studies conducted indicate that corporate ownership and board structures are related. Board characteristics are assumed to be endogenously determined, together with ownership characteristics (Y.T. Mak \& Yuan Li, 2001.). Also on the basis of the research work of Demsetz and Lehn (1985), work of Hermalin and Weisbach (1988), Mak and Yuan (2001), the emphasis is on the effect of the board characteristics. In their 
models, the authors analyze the determinants of management ownership and capital share held by outside shareholders. Morck et al., 1988 used board of directors' equity holdings as a proxy for managerial ownership. Some authors statistically conclude significant effect of Board composition on ownership structure. The board characteristics forming part of this study are board composition, board leadership structure and board size as also identified by Y.T. Mak \& Yuan Li (2001). La Porta et al (1999), Bebchuk et al (1999) and Wolfenzon (1999), Ungki and Chang Soo (2005) in their work identify the determinants of ownership structure of Koreans firms and conclude that debt and size affect ownership structure. Financial performance is a vital tool to several stakeholders. Financial Performance of a Company reports the financial health of a company that helps various investors and stakeholders take their investment decision. Different studies have used different measures of financial performance where some have used market based measures while others have focused on accounting based. Victoria Krivogorsky (2006) and then Ben Said Hatem (2014) study the interdependence between return on equity and ownership structure. $\mathrm{La}$ Porta, Shleifer and Vishny (2002), and Ben Said Hatem (2014) measure the impact of growth opportunities on ownership concentration by Tobin's Q ratio. Ben Said Hatem (2014), based on the work of Demsetz and Lehn (1985) tried to determine the impact of firm size on ownership structure. Ungki Lima \& Chang-Soo Kim (2003) also took firm size as a determinant of ownership pattern in their research.

Table 1: Variables used to ascertain the Factors Affecting Ownership Pattern

\begin{tabular}{|c|c|c|c|}
\hline S. No. & $\begin{array}{l}\text { Variable } \\
\text { Name }\end{array}$ & $\begin{array}{l}\text { Measurement \& } \\
\text { symbol used in } \\
\text { the study }\end{array}$ & Description \\
\hline 1 & $\begin{array}{l}\text { Financial } \\
\text { performance }\end{array}$ & ROE & $\begin{array}{l}\text { Return on Equity = Profit After Tax/Common } \\
\text { Stockholder's Equity (extracted from ACE } \\
\text { Equity). }\end{array}$ \\
\hline 2. & $\begin{array}{l}\text { Ownership } \\
\text { Pattern }\end{array}$ & OP & $\begin{array}{l}\text { Indian Promoters Shareholding \& Foreign } \\
\text { Promoters Shareholding quantify ownership } \\
\text { pattern. }\end{array}$ \\
\hline 3. & $\begin{array}{l}\text { Financial } \\
\text { leverage }\end{array}$ & $\begin{array}{l}\text { Debt Equity } \\
\text { Ratio (DER) }\end{array}$ & Debt / equity (extracted from ACE Equity). \\
\hline 4. & Firm Size & FS & Net Block (extracted from ACE Equity). \\
\hline 5. & Board size & BS & Total number of directors running the board. \\
\hline 6. & $\begin{array}{l}\text { No. of Non- } \\
\text { Executive } \\
\text { Directors }\end{array}$ & NXD & $\begin{array}{l}\text { Proportion (number) of non-executive } \\
\text { directors on board. }\end{array}$ \\
\hline 7. & $\begin{array}{l}\text { No. of } \\
\text { Independent } \\
\text { Directors* }\end{array}$ & ID & $\begin{array}{l}\text { Proportion (number) of independent directors } \\
\text { on board. }\end{array}$ \\
\hline 8. & $\begin{array}{l}\text { No. of } \\
\text { Women } \\
\text { Directors }\end{array}$ & WD & $\begin{array}{l}\text { Proportion (number) of female directors on } \\
\text { board. }\end{array}$ \\
\hline 9. & Duality & DL & $\begin{array}{l}\text { Leadership position of chairman and } \\
\text { managing director being held by same person } \\
(0 \text { is absence of duality and } 1 \text { is presence of } \\
\text { duality). }\end{array}$ \\
\hline 10. & $\begin{array}{l}\text { Growth } \\
\text { prospect }\end{array}$ & Tobin’s Q (TQ) & $\begin{array}{l}\text { Market capitalisation/book value of total } \\
\text { assets. }\end{array}$ \\
\hline
\end{tabular}

*Non-executive independent directors are counted in Independent Directors.

\section{Hypothesis Formulation}

Present study tries to figure out the precedents of ownership pattern in Indian context. Past studies have bifurcated the precursors of ownership pattern on the basis industry related or company-specific characteristics (Demsetz and Lehn, 1985), while some studies also consider legal origin of a country along with the initial two parameters (Bebchuk 1999).
Certain studies focus on two sets of variables i.e. industry-specific factors and venture-specific factors (Hongxin Zhaoa \& Gangti Zhub, 1998). The current study attempts to segregate the determinants of ownership pattern into three broad categories i.e. firm levels signals, market signals and board composition.

Under firm level sources, ownership pattern derives its value from financial performance, financial 
leverage and firm size; all indicate firm's idiosyncratic ability.

The market signals are extensively predictable signals to conclude ownership pattern. Tobin's Q (a proxy of prospects of future growth and earning) indicates that apart from interpreting companies past performance from historical financial statements and market performance from market signals; investors may also attach substantial weight to the growth prospect there by affecting ownership pattern. Cho, 1998 found that firm performance affects ownership structure.

Y.T. Mak \& Yuan Li (2001) study the interrelationships among corporate ownership and board structure characteristics. The proportion of outside directors is negatively related to board size. The use of a dual leadership structure is positively related to blockholder ownership.

The individual hypothesis is framed for each determinant of ownership pattern in the subsequent section that explains the theoretical background for the relation of each factor with ownership pattern.

\section{Financial performance}

Good financial performance in the past is always important. Surplus always serves as a basin for meeting potential contingencies. We measure the performance of firm by Return on equity and this ratio is calculated as net income to shareholders' funds. A high value of this ratio designates that the firm is more profitable. Investors always try to benefit by increasing their holdings. Hence good financial performance is expected to have a positive impact on ownership pattern (Ben Said Hatem, 2014).

Hypothesis 1: There is a positive interdependence between return on equity and ownership structure.

\section{Financial leverage}

"Leverage is the employment of an asset or funds for which the firm pays a fixed cost of fixed return. (J. C. Van Home). Debt is a resource of funding that can help a business cultivate more quickly. Leveraged finance is even more powerful, but the higher-thannormal debt level can put a business into risk.

The magnitude of debt depends on many factors. These include the availability of investment opportunities, uncertainty of future sales, the proportion of fixed costs to total costs, the nature of assets employed (in terms of tangibility or collateral), the access to stock market, the attitude toward corporate control, and the managerial philosophy are few (Ungki Lim, Chang-Soo Kim, 2005). Ben Said Hatem, 2014 expect negative influence of this variable.

Hypothesis 2: a high degree of leverage affects ownership structure negatively.

\section{Firm Size}

Firm size increase leads to monitoring costs becoming greater in these firms while economies of scale increase. Julio and Torre (2006) argue that the larger firm size is, the more costly it is for insiders and outsiders to increase their part in the capital of these firms. Ben Said Hatem (2014) also indicates that with the increase in firm size, it becomes very difficult for investors to increase their holdings.

Hypothesis 3: There is a negative interdependence between firm size and ownership structure.

\section{Board Size}

The board of directors is an apex decision making body in an organisation. It is conscientious of all policy formulation and strategic expansion within an organisation. Board of directors is the central internal control mechanism for monitoring managers. Jensen, 1993 identifies board size as a characteristic that affects the monitoring potential of a board. Y.T. Mak \& Y. Li, 2001 examine the determinants and interrelationships among corporate ownership and board structure characteristics and their findings indicate that corporate ownership and board structures are inextricably linked. In a large board, the coordination problem among members might lead to a loss of productivity, which may offset the gain from a large number of directors (Bang Nguyen Dang, 2005). In contrast to this, a large diversified board may bring constructive influence on ownership pattern. As also predicted by Y.T. Mak \& Yuan Li, 2001 diversified firms will have larger boards because of the need for more directors with expertise in different areas of business, and that as firms become more established, managers are promoted to directors and as a result, boards become larger.

Hypothesis 4: A diversified board size impacts ownership pattern positively.

\section{No. of Non-Executive Directors}

Cadbury Report, 1992 kicked off a debate about the key utilities and responsibilities on non-executive directors. The non-executive director's function is to create contribution to the board by providing independent oversight and constructive challenge to the executive directors. In the research conducted by Y.T. Mak \&Yuan Li (2001), examining the determinants and interrelationships among corporate ownership and board structure characteristics taking outside directors as a variable for study, they could not clearly identify whether a non-executive director is truly independent. The misclassification errors were taken as unsystematic thereby reducing the power of tests. This limitation has been overcome in this study where proper categorization has been worked out and hence the independent and non-executive directors have been taken separately for the purpose of this objective. Y.T. Mak \&Yuan Li (2001) is his study concluded that outside directors have a negative impact on board size 
as where a board has a high proportion of outside directors; it is more likely to be a small board. Zhaoyang Guo \& Udaya Kumara KGA, (2012) concluded that proportion of non-executive directors has negative impact on performance of firm thereby making the firm less attractive for investment.

Hypothesis 5: Non-Executive directors on the board impact ownership pattern negatively.

\section{No. of Independent Directors}

There are facets of directors' jobs where insiders are likely to be preferable. Inside directors are important because they convey information to top management and outside directors. Some scholars argue that a supermajority of independent directors will lead to worse performance (Bhagat and Black, 1999). Moreover, Hillman, Cannella and Paetzold (2000) talk about how in governance researches there is a requirement to look at skills separate from monitoring. They speculate it is also important to have board members with varied skills such as being insiders in the firm as business experts, support specialists may be on law and community prominent (e.g., members of a community organization). Low performance makes the firm a less striking venture to put in their money. Also Hermalin and Weisbach find that ownership is inversely correlated with the pro- portion of outside directors.

Hypothesis 6: Independent directors on the board impact ownership pattern negatively.

\section{No. of Women Directors}

Companies Act, 2013 has made it mandatory to have at least one women director on the board of specified companies. Despite frantic initiatives to draw women in corporate boards, board rooms largely remain rooms of men. The low representation of women in corporate boards remains a dominant reason for corporate attention to gender diversity, despite the fact that women may increasingly possess the same relevant skills and qualifications as men (Smith et al., 2006). In particular, the male-dominated nature of corporate board room has been mooted as a potential contributory factor to the collapse of WorldCom and Enron (Erhardt et al., 2003). Silvia Solimene, Daniela Coluccia \& Stefano Fontana, (2017) concluded that female directors are more likely professional figures, with experience. Renée B. Adams \& ECGI Daniel Ferreira, 2008 also showed that female directors have a significant impact on board inputs and firm outcomes thereby making investment in such companies lucrative.

Hypothesis 7: Women directors on the board impact ownership pattern positively.

\section{Duality}

Fama and Jensen, 1983 state that board composition is a fundamental determinant that affects board's capacity to control managerial actions. In case of my study when chairman is also the managing director, the power within the firms will be largely concentrated in one person's hands. Regulated firms are more likely to have single person holding both the positions of managing director and chairperson. Also in consistency with Brickley et al, 1997 argument, Y.T. Mak \& Y. Li, 2001find that MDs with longer tenures are more likely to also hold the chairperson's position as those who pass the test eventually earn the additional title of the board.

Hypothesis 8: Duality on the board impact ownership pattern positively.

\section{Growth Prospect}

Growth is another important facet of a firm, may be small or large. It is been argued that growth is an indispensable condition for the long run endurance of the firm in an uncertain and constantly changing environment (Downie, 1958, Marris, 1980). A higher Tobin's q suggests that the assets are used efficientlythat is, they are worth more within the firm than in alternative uses (Kurt A. Desender, 2009). It determines owners' equity stake holding in firms. Tobin's Q reflects growth opportunities and expectations of firms' future prospects (Cornett et al., 2007). Prasad S. Bhattacharya \& Michael A. Graham, 2009 inference that firms' existing and prospective future owners would make equity investments based on firm performance as well. Higher growth opportunities transmit a signal on the firm's financial and economic health. In this case, managers, or external investors are stimulated to increase their ownership structure to take benefit.

Hypothesis 9: Growth opportunities impact ownership structure positively.

\section{Panel regression results determining the factors affecting corporate reputation}

Ownership pattern draws from numerous resolves. The locus of ownership structure lies between the capacity of risk bearing, provision of finance and decision-making tasks of a firm. There are many financial and non financial factors that influence. The current section reveals factors affecting ownership structure formation process of Indian companies. Determinants of ownership pattern (measured through two proxies) are shown individually for each proxy in table 3 and table 4 where the dependent variable i.e. ownership pattern is changed in each table whereas the factors remain uniform throughout the analysis.

Table 3 describes panel regression results of factors affecting ownership pattern. This model describes 92 per cent variation in ownership pattern. Financial performance measured by ROE posits a significant positive impact on corporate reputation. Ownership 
pattern (taking percentage of Indian promoters' shareholding as proxy) is found to be appreciably and notably influenced by financial performance (p-value $0.00<0.01)$. All the other variables such as financial performance, financial leverage, firm size, board size, proportion of non-executive and independent directors, duality and growth prospect fail to have any important effect on ownership pattern as the p-values stand statistically insignificant.

Table 4 describes panel regression results of factors affecting ownership pattern and this model describes 92 per cent variation in ownership pattern. Financial leverage as measured by debt equity ratio has a significant impact on corporate reputation. In this model the shareholdings of foreign promoters is taken as proxy for ownership structure. Financial leverage as represented by debt equity ratio in this model portrays majorly negative (p-value $0.09<0.10$ ) impact on ownership pattern. Dual leadership structure (chairman and managing director) in our case shows a noteworthy and positive impact (p-value $0.00<0.01$ ) on formation or change of ownership structure. Regulated firms are more likely to have one person holding both the MD and chairperson positions. We also find that MDs with longer tenures are more likely to also hold the chairperson's position. This is consistent with Brickley et al, 1997 argument that CEOs (MD's in our case) who pass the test eventually earn the additional title of chairperson of the board. All the other variables such as financial performance, firm size, board size, proportion of non-executive and independent directors, women directors and growth prospect fail to have any important effect on ownership pattern as the p-values stand statistically insignificant.

\section{Conclusion}

The chapter attempts to elucidate the factors affecting ownership pattern building process in India. It is crucial for the corporate heads and senior managers to identify as to what constitutes a sound ownership structure. Table 4.2 summarizes the list of factors significantly affecting the reputation building process in India. It can be concluded from the analysis that a good financial performance serves as a building block for attracting investments in consistence with the international evidence according to which past financial performance is found to have significant repercussion in framing positive public image about the company. As regulated firms are more likely to have one person holding both the MD and chairperson positions, it is another essential forebear of ownership pattern. Another forerunner of ownership pattern is board size. Similarly low leverage is preferred by investors making the firm an attractive venture to invest in. Hence all the above implies that different determinants impact ownership pattern differently.

Table 2: List of factors significantly affecting ownership pattern in India

\begin{tabular}{|l|c|c|}
\hline $\begin{array}{c}\text { Determinants } \\
\text { of OP }\end{array}$ & IP & FrP \\
\hline FP & $+* * *$ & - \\
\hline FL & + & $-*$ \\
\hline FS & - & - \\
\hline BS & + & + \\
\hline NXD & - & + \\
\hline ID & - & - \\
\hline WD & + & + \\
\hline DL & - & $+* * *$ \\
\hline GP & + & + \\
\hline R square & 0.9221 & 0.9218 \\
\hline
\end{tabular}

Source: Own compilation

Note: One*; two $* *$ and three asterisks*** indicate statistical significance at the level of 10 percent; 5 percent and 1 percent respectively.

Notes: + sign denotes positive relation; - sign denotes negative relation; NA-not applicable; DrO-\% of Director Ownership; FrO-\% of Foreign Ownership; II-\% of shares held by Institutional Investors; IP-\% of shares held by Indian Promoters; FrP-\% of shares held by Foreign Promoters; FP-financial performance; FLfinancial leverage; FS- firm size; BS-board size; NXDnon-executive directors; ID-independent directors; WD-women directors; DL-duality; TQ- tobin's q.

Table 3: Result of Panel Regression (Dependent Variables-\% of shares held by Indian Promoters) Model 1

\begin{tabular}{|l|c|c|c|}
\hline \multicolumn{1}{|c|}{ Independent Variables } & \multirow{2}{*}{ Symbol } & \multicolumn{2}{|c|}{ Dependent Variable } \\
\cline { 3 - 4 } & & \multicolumn{2}{c|}{$\begin{array}{c}\text { \% of shares held by } \\
\text { Indian Promoters }\end{array}$} \\
\cline { 3 - 4 } & & Coefficients & p- value \\
\hline Financial performance (ROE) & FP & 0.024 & 0.001 \\
\hline Financial leverage (DER) & FL & 0.047 & 0.197 \\
\hline Firm Size & FS & -2.57 & 0.791 \\
\hline Board size & BS & 0.246 & 0.491 \\
\hline $\begin{array}{l}\text { No. of Non-Executive } \\
\text { Directors }\end{array}$ & NXD & -0.189 & 0.658 \\
\hline
\end{tabular}




\begin{tabular}{|l|c|c|c|}
\hline No. of Independent Directors & ID & -0.379 & 0.359 \\
\hline No. of Women Directors & WD & 0.218 & 0.655 \\
\hline Duality & DL & -0.823 & 0.494 \\
\hline Growth prospect (Tobin's Q) & GP & 0.124 & 0.143 \\
\hline R square & & 0.9221 & \\
\hline
\end{tabular}

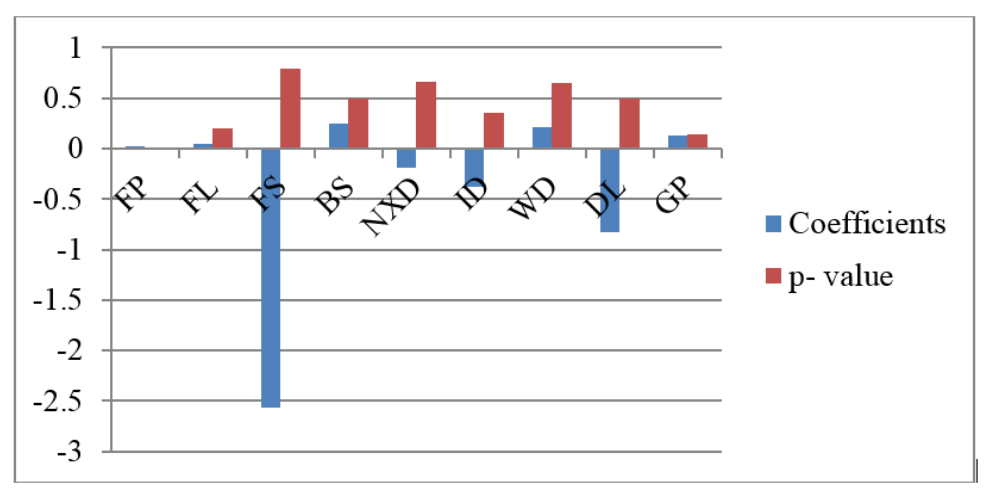

Fig. 1: Result of Panel Regression (Dependent Variables-\% of shares held by Indian Promoters)

Table 4: Result of Panel Regression (Dependent Variables-\% of shares held by Foreign Promoters) Model 2

\begin{tabular}{|l|c|c|c|}
\hline \multicolumn{1}{|c|}{ Independent Variables } & \multirow{2}{*}{ Symbol } & \multicolumn{2}{c|}{ Dependent Variable } \\
\cline { 3 - 4 } & & $\begin{array}{c}\text { \% of shares held by } \\
\text { Foreign Promoters }\end{array}$ \\
\cline { 2 - 4 } & & Coefficients & p- value \\
\hline $\begin{array}{l}\text { Financial performance } \\
\text { (ROE) }\end{array}$ & FP & -0.007 & 0.169 \\
\hline Financial leverage (DER) & FL & -0.043 & 0.097 \\
\hline Firm Size & FS & -3.63 & 0.958 \\
\hline Board size of Non-Executive & BS & 0.164 & 0.514 \\
\hline $\begin{array}{l}\text { No. NX } \\
\text { Directors }\end{array}$ & & 0.204 & 0.497 \\
\hline No. of Independent Directors & ID & -0.005 & 0.987 \\
\hline No. of Women Directors & WD & 0.004 & 0.991 \\
\hline Duality & DL & 2.625 & 0.002 \\
\hline Growth prospect (Tobin's Q) & GP & 0.015 & 0.798 \\
\hline R square & & 0.9218 & \\
\hline
\end{tabular}

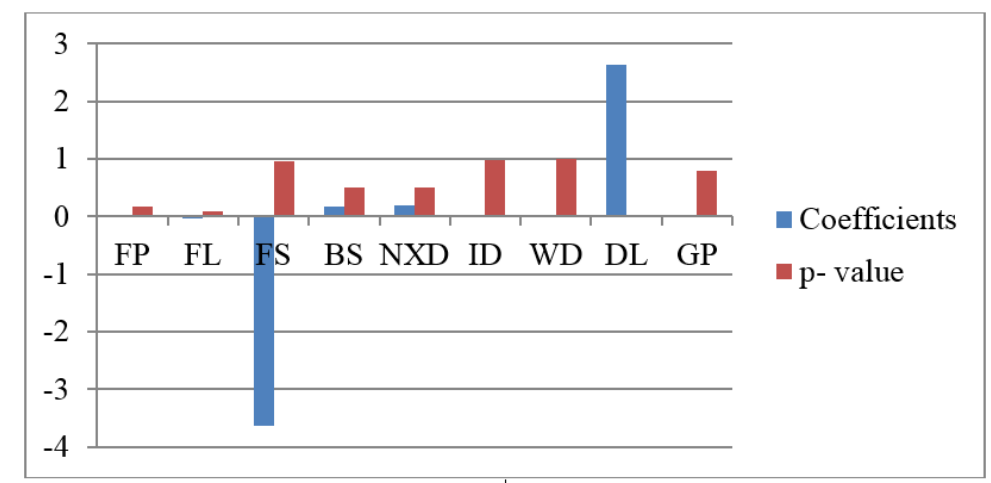

Fig. 2: Result of Panel Regression (Dependent Variables-\% of shares held by Foreign Promoters) 


\section{References}

1. Adams, Renée B. \& Ferreira, ECGI Daniel, 2008, Women in the Boardroom and Their Impact on Governance and Performance, http://ssrn.com/abstract=1107721.

2. Agrawal, A., Knoeber, C.R., 1996. Firm performance and mechanisms to control agency problems between managers and shareholders. Journal of Financial and Quantitative Analysis, 1996, vol. 31, issue 03, 377-397.

3. Bebchuk, L. A., \& Roe, M. J., (1999), A theory path dependence in corporate governance and ownership, Columbia Law School, The Center of Law and Economic Studies, Wolfenzon.

4. Berle, Adolph, Gardiner Means, 1932, The modern corporation and private property, NY,

5. Macmillan

6. Brickley, James, Jeffrey Coles, Gregg Jarrell, 1997, Leadership structure: separating the CEO and Chairman of the Board, Journal of Corporate Finance, Vol. 3, Issue 3, 189-220. Downie, 1958, Marris, 1980.

7. Bhattacharya, Prasad S. \& Graham, Michael A., 2009, On institutional ownership and firm performance: A disaggregated view, J. of Multi. Fin. Manag. 19 (2009) 370-394.

8. Bhagat, S. and Black, B. (1999) The Uncertain Relationship Between Board Composition and Firm Performance, Business Lawyer, 54(3), 921-963.

9. Cho, M.H., 1998. Ownership structure, investment, and the corporate value: an empirical analysis. Journal of Financial Economics 47, 103-121.

10. Chu, Ei Yet \& Cheah, Kooi Guan, 2004, Does Ownership Structure Matter? Evidence from Malaysian Equity Market, Corporate Ownership \& Control, Volume 4, Issue 1, Fall 2006.

11. Cornett, M.M., Marcus, A.J., Saunders, A., Tehranian, H., 2007. The impact of institutional ownership on corporate operating performance. Journal of Banking and Finance 31, 1771-1794.

12. Demsetz, H., and K. Lehn, 1985, The structure of corporate ownership: Causes and consequences, Journal of Political Economy 93, 1155-1177.

13. Desender, Kurt A., 2009, The relationship between the ownership structure and the role of the board, http://ssrn.com/abstract=1440750.

14. Erhardt, N., Werbel, J. and Shrader, C. (2003). Board of Director Diversity and Firm Financial Performance. Corporate Governance, 11(2): 102-111.

15. Fama, E.F., 1980, Agency problems and the theory of the firm, Journal of Political Economy 88, 288-307.

16. Fama, E.F. and M.C.Jensen, 1983, Separation of ownership and control, Journal of Law and Economics 26, 301-325.

17. Guo, Zhaoyang \& KGA, Udaya Kumara, 2012, Corporate Governance and Firm Performance of Listed Firms in Sri Lanka, Procedia - Social and Behavioral Sciences 40 ( 2012 ) $664-667$.

18. Hatem, Ben Said, 2014, Determinants of Firm Performance: A Comparison of European Countries, International Journal of Economics and Finance; Vol. 6, No. 10; 2014.

19. Hermalin, B., Weisbach, M., 1988. The determinants of board composition. RAND Journal of Economics 19, 589-606.

20. Hillman, A., Cannella, A. and Paetzold, R. (2000) The resource dependence role of corporate directors: Strategic adaptation of board composition in response to environmental change, Journal of Management Studies, 37: $235-256$.
21. Jensen, M.C. and W.H. Meckling, 1976, Theory of the firm: Managerial behavior, agency costs and ownership structure, Journal of Financial Economics 3, 305-360.

22. Jensen, M.C., 1993. The modern industrial revolution, exit and the failure of internal control systems. Journal of Finance 48, 831-880.

23. Julio, P., \& Chabela, De La T. (2006). The Role of Investment, Financing and Dividend Decisions in Explaining Corporate Ownership Structure: Empirical Evidence from Spain. European Financial Management, 12(5), 661-687. http://dx.doi.org/10.1111/j.1468036X.2006.00272.x

24. Krivogorsky Victoria, 2006, Ownership, board structure, and performance in continental Europe, The International Journal of Accounting 41 (2006) 176-197.

25. La Porta R, Lopez-De-Silanes and Shleifer A (1999), "Corporate Ownership Around

26. the World", Journal of Finance, Vol. LIV, No. 2, pp. 471 517.

27. La Porta, Rafael, Florencio Lopez-de-Silanes, Andrei Shleifer and Robert Vishny, 2002, Investor protection and corporate valuation, Journal of Finance 57, 1147-1170.

28. Mak. Y. T., \& Yuan, L. (2001). Determinants of corporate ownership and board structure: evidence from Singapore. Journal of Corporate Finance, 7, 235-256.

29. Morck, R., Shleifer, A., Vishny, R.W., 1988. Management ownership and market valuation: an empirical analysis. Journal of Financial Economics 20, 293-315.

30. Nguyen-Dang, Bang, 2005, Ownership Structure and Board Characteristics as Determinants of CEO Turnover in French-Listed Companies, HEC Paris.

31. Short, H., Keasey, K., Duxbury, D., 2002. Capital structure, management ownership and large external shareholders: a UK analysis. International Journal of the Economics of Business 9 (3), 375-399.

32. Shivdasani, A., 1993. Board composition, ownership structure, and hostile takeovers. Journal of Accounting and Economics 16, 167-198.

33. Santanu K Ganguli and Shail Agrawal, 2008, Ownership Structure and Firm Performance: An Empirical Study on Listed Mid-Cap Indian Companies, The IUP Journal of Applied Finance, Vol. 15.

34. Smith, N. and Smith, V. and Verner, M. (2006), "Do Women in Top Management affect Firm Performance? A Panel Study of 2,500 Danish Firms", International Journal of Performance Management, 55, 569-593.

35. Solimene, Silvia, Coluccia, Daniela \& Fontana, Stefano , 2017, Gender diversity on corporate boards: an empirical investigation of Italian listed companies, www.palgrave-journals.com/palcomms.

36. Short, H. 1994. Ownership, Control, Financial Structure and the Performance of Firms.

37. Journal of Economic Surveys, 8(3): 203-249.

38. Ungki Lim and Chang-Soo Kim, 2005, Determinants of ownership structure: An empirical study of the Korean conglomerates, Pacific-Basin Finance Journal 13, pp. 128.

39. Zhaoa Hongxin \& Zhub Gangti, 1998, Determinants of ownership preference of international joint ventures: new evidence from Chinese manufacturing industries, International Business Review 7 (1998) 569-589. 